\title{
BRANDING HIGHER EDUCATION: THE CASE OF MALAYSIAN HIGHER EDUCATION PROMOTION ON THE INTERNET
}

\author{
Alexandra Samokhvalova \\ AFRASO, Goethe-University Frankfurt, Frankfurt am Main, GERMANY \\ Email: a.samokhvalova@gmx.de
}

Published online: 25 September 2017

To cite this article: Samokhvalova, A. 2017. Branding higher education: The case of Malaysian higher education promotion on the Internet. Kajian Malaysia 35(2): 87-104. https://doi.org/10.21315/ $\mathrm{km} 2017.35 .2 .5$

To link to this article: https://doi.org/10.21315/km2017.35.2.5

\begin{abstract}
A booming middle class, new attractive study destinations and a resulting shift in student mobility trends have recently established a new dynamic in international higher education. To stay competitive, countries apply marketing strategies to promote and "sell" their higher education to international students-cumcustomers. With the growing use of the Internet to research study destinations, the role of online channels in higher education promotion is becoming increasingly important. The current study investigates the case of Malaysian higher education branding in cyberspace. By applying content analysis to the two major higher education online platforms, this study identifies the core brand values of Malaysian higher education and evaluates their coherence. The research findings demonstrate that both platforms combine nation and higher education branding efforts to create a harmonised image of the national higher education system. Additionally, several suggestions are made concerning the optimisation of the architecture and information presentation of the websites to enhance their attractiveness for users. Finally, the necessity of further investigation into higher education branding for the successful implementation of internationalisation policies in Malaysia is emphasised.
\end{abstract}

Keywords: Malaysia, higher education, nation branding, core brand values, online branding 


\section{INTRODUCTION}

According to the recent PricewaterhouseCoopers Report (Hawksworth and Chan, 2015), the world will see a major shift in economic power to Asia over the next 30 years. Similarly, Asia will transform the higher education sector and set new transnational mobility trends. The notion of Asia changing its role from supplier of students to provider of higher education has been broadly discussed in recent academic discourse. With the rapid growth of higher education as a lucrative business and revenue generator for state budgets, governments in Asia adopt a wide range of strategies to make higher education attractive for international students, including branding, marketing campaigns and easing of immigration regulations.

One of the most recent studies on international student destination choice has revealed the growing role of online channels in the search for study destinations (Howard, 2013). According to the findings of Howard (2013), more and more students use predominantly or even exclusively Internet sources while researching their higher education opportunities abroad. Thus, online information channels should be given priority among marketing tactics to attract foreign students.

Malaysia is a prominent example of an emerging higher education provider, aiming at attaining its ambitious goal of becoming a global education hub with 200,000 tertiary students arriving from abroad by 2020. Moreover, higher education has a big share in the national branding of Malaysia, helping it "stand out" in the global arena. As online research has been gaining increased attention among international students, Malaysia established two online platforms that are used to promote national higher education. The platforms, which have similar functions of providing potential students with information on study opportunities in Malaysia, also contribute greatly to creating an image, or brand, of the national higher education with its specific characteristics. This projected image can, to a large extent, affect the decision-making process of prospective students. Hence, it is of utmost importance for the government to send a clear and distinctive image of Malaysian higher education through these online channels.

The question invoked by the above described context is what does the higher education brand that is created by these online channels look like, and is the communicated image harmonious and clear. The current paper explores the main values and characteristics the two online platforms www.studymalaysia.com and www.educationmalaysia.gov.my present to the Internet audience to promote higher education in Malaysia. The empirical part of the research is based on data obtained from the websites www.studymalaysia.com and www.educationmalaysia.gov.my. Additionally, a comparison of the main values and characteristics of the Malaysian higher education system that is communicated by the websites is carried out to assess their coherence ${ }^{1}$. Conceptually, the paper is linked to the literary discourse 
about nation branding and higher education branding with a special focus on strategies used by states to succeed in it.

The paper aims to fill the gap of existing literature on higher education branding initiatives, underlining the growing importance of online brand communication, which is often overseen both in the academic discourse and by policymakers and marketers. Furthermore, the results of the empirical analysis and comparison of the two websites can serve as a reference point and basis for improvements in the higher education branding strategies in Malaysia. This paper has been divided into four parts. The first part addresses the theoretical dimension of the research, giving a brief synopsis of the relevant literature and study context. The second part concentrates on the methodology applied in this study. The third section presents the findings of the study and is followed by a brief conclusion and discussion. The final part establishes an agenda for future research on the study topic.

\section{LITERATURE REVIEW AND STUDY CONTEXT}

\section{Defining Nation Branding}

Facing the sweeping power of globalisation, countries all over the world have been challenged to compete with one another to secure their place in the market. The same powers have spurred global higher education to transform and become more commercialised. Being a "public good" for centuries, national higher educations have recently faced the challenge of becoming more business-like to stay competitive. Marketing techniques, which had earlier been applied to products only, are now being adjusted to promote higher learning institutions. Universities and colleges employ marketing specialists by creating their own brands with logos, catchy mottos and other attributes of advertising campaigns we are used to seeing in TV commercials. Moreover, promoting national higher education has recently become a very important part of nation branding for many countries. As claimed by Sataøen (2015), "different higher learning institutions become part of nation branding practices as they are used to promote the country for foreign students, employees and other stakeholders".

Nation branding is widely referred to as a very complex and controversial concept, which sometimes has a negative aspect to it, being criticised for overemphasising the importance of commercialisation and marketing practices (Dinnie, 2015). Nevertheless, more and more countries across the globe are turning to nation branding as the means of enhancing their competitive power. As argued by Anholt (2005), a practicing consultant on nation branding matters and 
one of the leading authorities in the field worldwide, "a powerful nation brand provides a crucial competitive advantage" for a country. While nation branding is considered to be a recent phenomenon, some authors claim that particular images or "brands" of countries have always existed. Anholt (2007) and Olins (2002), two major advocates of nation branding, share the opinion that the concept is not novel. Olins (2002) even claims that countries have been constantly "branding and rebranding" themselves throughout history. Another popular view on nation branding origins is its continuation of public diplomacy, a well-known concept of government-initiated practices directed at influencing the foreign public with the aim of advancing national interests and implementing foreign policies. Many authors research connections between the two concepts and their similarities and differences (Szondi, 2008; Gilboa, 2008). Some academics even relate nation branding to a concept of cultural diplomacy and argue that it helps to shape the collective identity of a country (Kaneva, 2011).

Even though definitions of nation branding are manifold, the notions of the reputation and image of a country appear in most of them like a red thread. Therefore, the paper chooses to follow the definition given by Fan, who perceives nation branding as "a process by which a nation's images can be created, monitored, evaluated and proactively managed to improve or enhance the country's reputation among a target international audience" (Fan, 2006: 6). Fan also argues that even though the nation branding phenomenon has been widely discussed in academic literature, a sound conceptual framework of it is missing (Fan, 2006; Dinnie, 2015). Thus, he warns against misconception and interchangeable usage of the terms "identity", "image" and "reputation" in relation to nation branding. While "identity" stands for the self-perception of a nation, image and reputation are both parts of the process of communication between national and international counterparts. The image of a nation, according to Fan, is "what a nation's people want the world to understand is most central, enduring and distinctive about their nation", while "reputation is a particular type of feedback received by the nation from the outside world, concerning the credibility of the nation's identity claims" (Fan, 2006: 5).

Many publications on nation branding focus on single countries and display a marketing approach towards the topic. In her classification of nation branding literature, Nadia Kaneva allocates these studies to the technical-economic category, where countries adopt nation branding strategies to enhance their competitive advantage in the global arena (Kaneva, 2011: 121). Most works in this category represent either success or failure stories of countries in nation branding endeavours. ${ }^{2}$ A number of authors also provide their view on the main reasons for countries to get involved in nation branding exercise, adopting new strategies and investing big sums of money in creating and advertising their "nation brands". While renowned practitioners such as Anholt see the main advantage of nation 
branding in enhancing international competitiveness of a country, others such as Olins (1999) also see its importance in the remolding of the national identity. Fan (2006) and Dinnie (2015) claim that nation branding is necessary to strengthen the image of a nation abroad and to pursue the economic and political interests of the country.

\section{Higher Education Branding as a Part of Nation Branding}

In his book Nation Branding: Concepts, Issues, Practice (2015), Keith Dinnie notes the importance of outlining the industry sectors, in which the country may have a competitive advantage. According to Dinnie, sectors such as tourism, investment or education could be the main focus of nation branding initiatives. Education is indeed considered by many authors as an important part of nation branding (Sataøen, 2015; Gade, 2014). With globalisation forcing the higher education sector to transform and become more competitive, reputation and branding in higher education start to play a vital role. As Gray, Kim and Llanes (2003) claim, the branding of higher education institutions (HEIs) can be a powerful tool in providing competitive advantage to a country as a whole.

Higher education branding as a part of nation branding is especially relevant for countries that prioritise higher education as one of their main economic drivers. Malaysia is a prominent example, with higher education as one of its "key economic areas" that should fully develop the country by 2020. Responding to the modern trends in the higher education realm such as internationalisation and excellence initiatives, Malaysian higher education has managed to transform itself into a major player on the global market (Samokhvalova, 2015). According to the Minister of Higher Education, Datuk Seri Idris Jusoh, the most recent report by UNESCO has placed Malaysia among the top 10 destinations for tertiary studies globally (Bernama, 2016). In 2014, Malaysia welcomed 135,000 international students from more than 160 countries, and Malaysia's Higher Education Strategic Plan has set the objective to reach the threshold of 200,000 international students by 2020 , which seems to be a realistic goal when considering the fast growth of the foreign student population in the country. ${ }^{3}$ In fact, several authors claim that Malaysia is rapidly shifting from a supplier of international students into a provider of higher education and is on its way to becoming "one of the critical markets" in international education (Hawthorne, 2008: 17; Mohd Ismail and Doria, 2014: 497).

Ambitious plans of Malaysia to "go global" increase the importance of creating a positive image of higher education on the international market. Shaping a recognisable "brand" of Malaysian higher education and promoting it could significantly increase the inflow of students into the country. As Bourke claims, the educational reputation of a country is a decisive factor in the choice of study destinations by students (Bourke, 2000: 115, 124). Lately, the Internet has 
been gaining position as the main channel of educational promotion and student recruitment. According to a recent survey by Howard, online research plays the key role in "the discovery phase" of students' search for study opportunities abroad. Importantly, national education promotion and a strong "brand" should be given priority because nine out of ten potential students search for a destination country and an appealing higher education system rather than for a specific school they want to attend (Howard, 2013). Thus, online student recruitment platforms should broadcast a clear and convincing image of higher education to persuade potential students.

Malaysia has two websites launched by the government to promote higher education and provide practical information for potential students on topics such as visa regulations, applications and the enrolment process. These websites serve as "entry gates" into Malaysian higher education, which are used to communicate the positive image and advertise the Malaysian higher education brand. The current paper will analyse the websites www.studymalaysia.com and www. educationmalaysia.gov.my to identify the core values that compose this brand.

\section{RESEARCH METHODS AND METHODOLOGY}

Data for this paper are collected from two primary sources, both of which constitute Internet sources: www.studymalaysia.com and www.educationmalaysia.gov.my. Studymalaysia.com, an online marketing media for Malaysian HEIs, was launched in December 1998 on the initiative of the then Minister of Education and current Prime Minister of the country Najib Tun Razak. The website offers insights into the higher education system in Malaysia and provides information on higher learning institutions, study programmes and scholarship opportunities. As stated on the website, the chief aim of this platform is to "project the good image" of Malaysian higher education and promote studying in Malaysia locally and internationally.

Educationmalaysia.gov.my is an official website of Education Malaysia Global Services (EMGS), a company that was founded and is wholly owned by the Ministry of Education Malaysia. The company itself and its website were launched in the beginning of 2013. Apart from providing information about studying in Malaysia, EMGS operates as a One-Stop-Center for international students by managing and processing student visas (also online via the website). Thus, the scope of services provided by educationmalaysia.gov.my is broad, and the aims of this platform, in addition to the promotion of Malaysian higher education, include monitoring of foreign students in the country and income generation through provision of extra services such as health insurance.

Both text and visual materials presented on the websites were scrutinised during the empirical research phase. Organisational structure and information 
presented on the websites were also analysed to state which information units are given priority or special emphasis. The obtained data were analysed by employing the method of qualitative content analysis. According to Downe-Wamboldt, content analysis is "a research method that provides a systematic and objective means to make valid inferences from verbal, visual, or written data to describe and quantify specific phenomena" (Downe-Wamboldt, 1992: 314). A simpler definition of content analysis, which is offered by Opoku, Abratt and Pitt, describes it as "a technique for gathering and analysing the content of a text" (Opoku, Abratt and Pitt, 2006: 25). Compared to its quantitative counterpart, qualitative content analysis is more flexible in data sampling and provides for subjective interpretation of the content of text and visual data, identifying its meaning (Zhang and Wildermuth, 2009). Content analysis can be used on all types of written texts no matter where the material comes from, which is particularly relevant for the current research that uses texts and visuals obtained from the Internet.

As Bengtsson describes in her latest work (2016), when applying the content analysis method, researchers have to choose between manifest or latent analysis. According to her, by applying manifest analysis, researchers describe the "visible and obvious" from the text, often referring back and citing the text units. In contrast, latent analysis is extended to an interpretive level in which the researcher seeks the underlying meaning of the text. In other words, manifest analysis operates at a "surface level", staying closer to the text, while latent analysis allows researchers to interpret the extracted data and search for hidden meaning (Burnard, 1991; Bengtsson, 2016).

The current paper aims to combine manifest and latent analyses to scrutinise the websites. This approach is defined by Hsieh and Shannon as summative content analysis, which at the first stage analyses the appearance of particular words and contents in textual material and later interprets the content (Hsieh and Shannon, 2005: 1283-84). Thus, the paper first analyses the organisational structure and information architecture ${ }^{4}$ of the website, identifying the themes that are given priority. This is followed by the text analysis and interpretation in search of core brand values that are communicated by the online platforms. Information from the home page and all links and roots linked to the home page is copied into a text document, which is eventually coded so that the core values can be identified.

Gylling and Lindberg-Repo describe core brand values as the heart of the brand, which should reflect the values of the organisation and include components that make the brand unique and valuable (Gylling and Lindberg-Repo, 2006: 264). These core values can also be described as main characteristics that make a brand distinctive and recognisable. In the context of higher education branding, core brand values are special features of higher education that are being presented to the broad audience with the aim of promoting higher education and attracting students. These core values form a brand identity. Harris and de Chernatony argue 
that brand identity is "an organisation's ethos, aims and values that create a sense of individuality which differentiates a brand" (Harris and de Chernatony, 2001: 442). Many authors simply describe it as a message from the seller to the customer that presents a product/service (Goi, Goi and Wong, 2014: 61-62). Brand identity in higher education can be defined as a number of characteristics of the brand, which are presented to the students-cum-customers.

By analysing the contents of these websites, the current paper has the goal of identifying the core brand values of Malaysian higher education and comparing the websites to uncover any patterns and define the brand identity of Malaysian higher education. A comparison of the core values will also help to assess the level of coherence of the brand values communicated by the different platforms in cyberspace $^{5}$, which is crucial for creating a clear and persuasive higher education image.

The main limitation of this research lies in the relatively small scope and homogenous nature of the data. Unfortunately, such data collection methods as interviewing and personal observations were not available to the author during the research process. However, the author plans to embark on further empirical research on the topic to obtain additional information for analysis and increase the validity of results.

Moreover, qualitative content analysis method is fundamentally interpretative, which makes it subjective and biased. To reduce the level of subjectivity, the author attempts to keep a balance between the descriptive and interpretative parts of analysis while presenting the results. The paper follows the advice of Michael Quinn Patton, who claims that a good report should provide sufficient description to allow the reader to understand the basis for an interpretation and sufficient interpretation to allow the reader to understand the description (Patton, 2002: 503-504).

\section{RESULTS}

\section{Study Malaysia Online}

The website www.studymalaysia.com (Study Malaysia Online) was launched on 28 December 1998 by the Ministry of Education and constitutes the first Malaysian online platform providing abundant information on higher education opportunities in the country. The main impulse for starting this website was driven by the major transformations in the higher education system of Malaysia at that time. With the privatisation and corporatisation reforms occurring in the mid-1990s, the number of private institutions, branch campuses of foreign universities and twinning programmes in the country mushroomed. As a result, a comprehensive 
information portal was needed to provide students with information about the fast-changing higher education system and to promote new institutions. Later, in line with the new governmental policy of turning Malaysia into a global higher education hub, the website became an online platform to recruit international students and promote the Malaysian higher education brand. Today, as it is stated in the "Corporate Information" section of the website, Study Malaysia Online aims at promoting Malaysian higher education locally and internationally "in line with the government's vision to make Malaysia a centre of Educational Excellence".

The website contains information about various higher education providers including public and private universities, colleges and polytechnics, their study programmes and the facilities they offer. A search engine, placed directly on the homepage (first page), allows users to search for specific institutions and/or courses of interest. The homepage serves as a navigation page, which leads to various subpages with articles on the topic and displays a newsfeed on education issues ${ }^{6}$ and scholarship opportunities. Although the website interface is generally userfriendly and easily comprehensible, with links to subpages and interaction pages where users can sign up and create an account to easily access their search history and use additional online services, the homepage is overloaded with advertisement. Flashy oversized commercial banners of private universities and colleges pop up immediately at the opening of the webpage and occupy about two-thirds of the user's screen. The banners are quite distracting and create an immediate impulse to close the website. Furthermore, they generate an image of the platform being overly commercial and concerned about advertising more than providing information. Thus, the organisational structure of Study Malaysia Online should be optimised. Clearly, advertising banners serve as a revenue generator and cannot be removed completely, but the homepage can be reorganised to appear more welcoming.

Concerning information architecture, the website contains information on institutions and their programs, scholarships, articles about student life in Malaysia and tips for international students. The provided information is thorough and accurate. However, a major shortcoming of information presentation is the perplexing structure of the subpages. The section titled "Student Info \& Guide" leads to the subpage for Malaysian students, while the Section "International Students" is the one containing the promised useful information for students. This can easily lead to confusion on the user side. In addition, the information provided by the platform is not balanced and is repetitive as similar articles appear in different sections on different pages. For example, the subsection "Higher Education in Malaysia" in the section for Malaysian students contains several of the same articles as the subsection "The National Education System" for international students. An easy solution in this case would be the restructuring of the website to avoid repetition and confusion among users. 
Regarding the issue of higher education branding on the website, the article "Studying abroad - where next? Your higher education opportunities in Malaysia" in the section for international students is of particular importance. The text resembles advertising brochures, enumerating Malaysia's main achievements and the advantages of its higher education sector. The article is structured as a list of reasons for students to choose Malaysia as their study destination. The first paragraph of the text gives users a summary and outlines most of the core brand values, which are further repeated and emphasised in other subsections of the website:
Malaysia welcomes all international students from primary to tertiary levels, offering quality education that is more affordable than you may have thought. In addition to home-grown schools and universities, Malaysia has world renowned international schools and universities setting up branch campuses in the country to provide world-class education opportunities to both Malaysian and international students.

These lines describe higher education in Malaysia as having the following core values: quality, affordability, international reputation and excellence. Notably, affordability of education is given special attention in the article "Cost of studying and living in Malaysia", which not only presents figures regarding Malaysia but also demonstrates its competitive advantage by comparing those costs with most popular student destinations, such as the USA, Australia and the UK. To summarise, the article argues that Malaysia is a real "value-for-money" option, as it offers abundant study options at low cost.

Study Malaysia Online not only provides information regarding higher education sector but also promotes Malaysia as an attractive tourist destination country. To give an illustration, two articles narrate the fast development and achievements of Malaysia in the economic, political and social realms. For instance, the text with the title "Malaysia's excellent accomplishments" depicts Malaysia as politically stable, economically prosperous and socially harmonious. Additionally, its international standing as "a role model for new industrialised nations" plays an important role in the promotion of the country, emphasising its good reputation and growing prominence as "a global participant in today's world".

The core values of the Malaysian higher education brand, extracted from www.studymalaysia.com by means of analysing its textual materials, are illustrated in Table $1 .^{7}$

As observed in the Table 1, higher education in Malaysia is presented on www.studymalaysia.com as affordable education of high quality and international reputation. Additionally, Malaysia is portrayed as a progressive and fast-developing nation, balancing achievements in the economic sector with preserving cultural heritage and peace and stability among various nations, religions and cultures 
within its territory. Thus, Study Malaysia Online promotes both the national higher education and the country as a whole, combining higher education and nation branding efforts.

Table 1: Core values of Malaysian higher education as a brand, communicated through www.studymalaysia.com ${ }^{8}$

\begin{tabular}{|c|c|}
\hline Text unit & Core brand value \\
\hline $\begin{array}{l}\text { Quality of education is of global standard } \\
\text { Quality education, assured by legislation } \\
\text { [Malaysia] has a reputation as a provider of quality education }\end{array}$ & Quality \\
\hline $\begin{array}{l}\text { A regional education hub offering world-class education } \\
\text { [Malaysia] provides world-class education opportunities to both } \\
\text { Malaysian and international students } \\
\text { Malaysia is ranked the world's } 11 \text { th most preferred education destination } \\
\text { in the world among international students by UNESCO }\end{array}$ & $\begin{array}{l}\text { Excellence, } \\
\text { world-class }\end{array}$ \\
\hline $\begin{array}{l}\text { The affordable cost of quality higher education } \\
\text { Low cost of living and affordable tuition fees } \\
\text { Malaysia welcomes all international students from primary to tertiary } \\
\text { levels, offering quality education that is more affordable than you } \\
\text { may have thought }\end{array}$ & $\begin{array}{l}\text { Affordability, } \\
\text { value-for-money }\end{array}$ \\
\hline $\begin{array}{l}\text { The tremendous growth of the Malaysian higher education sector over } \\
\text { the last two decades has helped to put Malaysia on the international } \\
\text { playing field... } \\
\text { World-renowned international schools ... setting up branch campuses } \\
\text { There are about } 110,000 \text { international students from more than } 100 \\
\text { countries studying in Malaysia - testimony that Malaysia is a popular } \\
\text { choice for international students }\end{array}$ & $\begin{array}{l}\text { International } \\
\text { reputation }\end{array}$ \\
\hline $\begin{array}{l}\text { Malaysia's multi-faceted make-up } \\
\text { The multicultural community of Malaysia supports the institutions' aim } \\
\text { to make its students global citizens } \\
\text { Exciting multi-cultural environment }\end{array}$ & $\begin{array}{l}\text { Diversity, } \\
\text { multi-culturalism }\end{array}$ \\
\hline $\begin{array}{l}\text { Malaysia has evolved remarkably into a prosperous nation } \\
\text { One of the most developed infrastructures in Southeast Asia } \\
\text { It [Malaysia] has soared like an eagle, evolving into a high technology } \\
\text { nation }\end{array}$ & $\begin{array}{l}\text { Dynamism, } \\
\text { rapid development }\end{array}$ \\
\hline
\end{tabular}

\section{Education Malaysia}

The website www.educationmalaysia.gov.my (Education Malaysia) was launched in February 2013 as an online platform of the Education Malaysia Global Services (EMGS) company. EMGS was established as a company limited by guarantee under Malaysian law and is wholly owned by the Ministry of Education. With 
the "boom" in the inflow of international students into the country around 2010, the government had to tighten the immigration regulations for students to cut the ever-increasing cases of visa fraud. In this context, EMGS was founded as an organisation that oversees student visa matters, including applications and renewal of student passes online. Moreover, since the new regulation that requires all foreign students to obtain a Student Pass at EMGS, www.educationmalaysia.gov. my is a must-visit for all international students planning to obtain higher education in Malaysia. Accordingly, the scope of website functions, in addition to promoting Malaysia as an education hub, includes processing and management of student visa issuing and tracking, facilitation of health insurance coverage and compulsory medical screenings upon arrival to Malaysia, and information services concerning HEIs and programmes for prospective students.

As the primary function of the website is the facilitation of student visa applications, the home page of www.educationmalaysia.gov.my immediately directs students towards the online application form. Additionally, a search engine is placed on the homepage that allows prospective students to browse higher learning institutions and courses offered in Malaysia. Both homepage and consumption pages, containing information about visa application, study opportunities and living in Malaysia, are user-friendly and simple to navigate. Furthermore, the subsections "Five easy steps to study in Malaysia" and "FAQ (Frequently asked questions)" deserve high praise for presenting useful information in an easy-tocomprehend and well-structured way. Unlike the Study Malaysia Online platform, the Education Malaysia website does not contain advertising banners, which in combination with the appearance of the Ministry of Education logo on every webpage makes the platform appealing to users as an official and therefore reliable source of information.

As far as information architecture is concerned, the website provides details on educational opportunities and advantages of living in Malaysia in separate categories such as "Plan Your Studies", "Why Malaysia" and "Lifestyle". Although the articles within these categories are well-structured, there is an imbalance in terms of the number of articles that are subsumed under each category. Comparatively, the "Plan Your Studies" category has only three article that explain the different types of higher education institutions in the country while "Why Malaysia" and "Lifestyle" each contains four articles with numerous "catchy" pictures of Malaysia's main attractions. The category of "Why Malaysia" consists of the subsections "Quality Education", "Reasonable Cost of Living" and "Safe and Stable Environment", only two of which are concerned with higher education in the country. In consequence, this imbalance shifts attention away from the promotion of Malaysian higher education. Additionally, a general overview of the historical development of higher education in Malaysia is missing from the website materials. 
In contrast, the articles dealing with the promotion of Malaysia as an attractive country are numerous and accompanied by large-sized colourful visuals. The obvious focus of the section "Lifestyle" lies in promoting Malaysia as an appealing tourist destination rather than an education hub because of subsections such as "Paradise for Food Lovers" or "Holiday Attractions". Furthermore, a separate article in the section "Why Malaysia" is dedicated to depicting Malaysia as one of the world's most peaceful and politically stable country that offers both a dynamic environment and cosmopolitan lifestyle for students. To summarise, the focus of information in the website lies on the nation branding of Malaysia. This could be because the platform is mostly directed at students who have already made a decision about studying in Malaysia and are about to embark on their visa application procedure. Thus, they would rather focus on information about student visa application process and guidelines for living in the country.

Table 2: Core values of Malaysian higher education as a brand, communicated through www.educationmalaysia.gov.my9

\begin{tabular}{|c|c|}
\hline Text unit & Core brand value \\
\hline $\begin{array}{l}\text { The country's Ministry of Higher Education monitors all institutions to } \\
\text { ensure they adhere to the highest standards } \\
\text { Many students ... found Malaysia to be the ideal choice to obtain a high- } \\
\text { quality degree } \\
\text { We [in Malaysia] offer excellent internationally-recognised qualifications }\end{array}$ & Quality \\
\hline $\begin{array}{l}\text { The affordable cost of quality tertiary education is one of many good reasons } \\
\text { why international students choose Malaysia } \\
\text { One of the main attractions Malaysia holds for foreign students is the } \\
\text { affordability factor } \\
\text { Aside from affordable tuition fees, another great reason to study in Malaysia } \\
\text { is the relatively low cost of living }\end{array}$ & Affordability \\
\hline $\begin{array}{l}\text { Malaysia is one of the world's most peaceful and politically stable countries } \\
\text { The fruit of decades of industrial growth and political stability } \\
\text { An atmosphere of mutual respect and tolerance }\end{array}$ & $\begin{array}{l}\text { Peace and } \\
\text { stability }\end{array}$ \\
\hline $\begin{array}{l}\text { An often-cited role model for other nations on the road to development } \\
\text { Malaysia boasts of being one of Southeast Asia's most vibrant economies } \\
\text { There are strong foundations, on which Malaysia can rely as it moves ahead } \\
\text { with efforts to become a high-income, innovation-based society }\end{array}$ & Dynamism \\
\hline $\begin{array}{l}\text { The stable relationships between the ethnic groups } \\
\text { Preservation of the balance between the main ethnic groups and access to } \\
\text { the national wealth have been delicately balanced with concessions } \\
\text { and compromises } \\
\text { The structure of government allows the diversity of the country's peoples and } \\
\text { regions, its long-standing traditions, its contemporary pluralism and its } \\
\text { sense of consensus to be encompassed within the political system }\end{array}$ & $\begin{array}{l}\text { Diversity, } \\
\text { multi-culturalism }\end{array}$ \\
\hline
\end{tabular}


After applying the latent content analysis method to the texts on www. educationmalaysia.gov.my, the following core values of higher education in Malaysia are identified: quality, affordability, peace and stability, dynamism and diversity. Examples of the text units that provide these core values are outlined in Table 2.

As seen from Table 2, Education Malaysia does not emphasise such values as "world-class" or "international reputation" in communicating the Malaysian higher education brand but rather promotes affordability and quality. In contrast, nation branding of Malaysia is given priority on the website, with such latent core values as "peace and stability" and "dynamism" among the most frequently incorporated in texts.

By comparing www.studymalaysia.com and www.educationmalaysia. gov.my, their similarities and differences in terms of organisational structure and content are revealed. Both websites declare Malaysian higher education promotion as one of the main objectives. Although the Education Malaysia webpage is better structured and presents a user-friendly interface and navigation, it does not contain such detailed information on the higher education system as www. studymalaysia.com. It can be assumed that if Study Malaysia Online follows the recommendations of this paper and restructures several subsections of its website to avoid confusion, it would be a better platform for higher education promotion than its counterpart. Regarding its wider scope of functions and provision of services, www.educationmalaysia.gov.my is more oriented towards users who are either searching for the first introduction to Malaysia as a study destination or who are already close to enrolling themselves as students. As a result, the website contains practical information on visa application procedures and an overview of the main attractions of Malaysia rather than detailed information about the higher education system. In this regard, the two websites appear to complement each other and avoid duplicating the same information.

A comparison of the core brand values communicated by the two websites reveals their harmonisation. To a large extent, the same core values have been used to promote higher education and Malaysia as a study destination. However, the difference can be observed in the focus of the websites on different values. Thus, www.studymalaysia.com emphasises "world-class" and "international reputation", while www.educationmalaysia.gov.my focuses more on nation branding, promoting Malaysia as a "dynamic", "diverse" and "peaceful" country. This implies that the Education Malaysia's portal places greater emphasis on the promotion of the country as a tourist destination which would appeal to those students who are searching for a combination of educational and touristic experiences. 


\section{CONCLUSION AND DISCUSSION}

The current study was conducted with the aim of analysing the two major online platforms for higher education promotion in Malaysia and determining the core values of the national higher education brand. The following core values of the higher education brand have been identified: quality, affordability, international reputation and excellence. Additionally, the websites promote the image of Malaysia as a dynamic, diverse and peaceful country. The research has found that the two websites communicate the same core values, thus creating a coherent and clear image of the higher education and the country as a whole. It is evident from the study that both platforms combine efforts of nation and higher education branding. This tactic is considered effective because international students tend to focus on what a destination country has to offer to them apart from higher education.

The only major difference between the two platforms lies in terms of information that is being communicated. While www.studymalaysia.com provides abundant information about the higher education system, www.educationmalaysia. gov.my puts more effort into nation branding by advertising tourist attractions and modern lifestyle of Malaysia.

This research provides a useful analysis of the online platforms, which create and communicate the Malaysian higher education brand in cyberspace. Moreover, the findings of this study have a number of practical implications and suggestions for the stakeholders in the higher education sector of Malaysia. First, more attention should be paid to online promotion of the Malaysian higher education because the Internet is becoming the main channel of international student recruitment. Second, the current analysis suggests that the information of Study Malaysia Online should be restructured and the advertising reduced to make the website appear more user-friendly. Third, Education Malaysia should consider including more information concerning the structure of higher education in Malaysia and other higher education materials on its website.

Following its initial objective, the article has contributed to the research field by adding new knowledge about online higher education branding and core values of the Malaysian higher education brand in cyberspace. Notably, further research should be undertaken to identify the core values of this brand at the university level. Therefore, the natural progression of the current work would be to analyse various branding initiatives of public and private higher learning institutions in Malaysia and compare the results with the findings of this study. Such research is necessary to determine whether higher education branding at national and university levels is harmonised and creates a coherent and persuasive image, which is crucial for the successful internationalisation of higher education. 


\section{ACKNOWLEDGEMENTS}

This study was funded by "AFRASO - Africa's Asian Options", funded by the Federal Ministry of Education and Research (BMBF), Germany.

\section{NOTES}

1. Coherence of brand values is required to shape a congruent brand. Coherent brand values are those values that do not contradict each other and create a uniform image that has very little potential of being misinterpreted.

2. Many similar articles are published in the Place Branding and Public Diplomacy (former Place Branding) or the Journal of Brand Management. For example, see Endzina, I. and L. Luneva, "Development of a National Branding Strategy. The Case of Latvia," Journal of Place Branding 1, No.1 (2004): 95-105; Gilmore, F. A., "Country - Can it be Repositioned? Spain - The Success Story of Countrybranding," Journal of Brand Management 9 (2002): 281-293; Wetzel, F., Brand England, Place Branding 2, No. 2 (2006.): 144-154.

3. At the end of 2014, Malaysia hosted approximately 135,500 international students, studying in public and private higher education institutions as well as international high schools. That was an increase of $16.5 \%$ from 2013, according to the Malaysian newspaper Sun Daily (Samokhvalova, 2015).

4. The author follows the definition by the Information Architecture Institute, which perceives information architecture as "the art and science of organising and labeling websites, intranets, online communities and software to support usability" (Information Architecture Institute, 2007).

5. Please note that the term "cyberspace" is interchangeable with "the Internet" in the current study. No further theoretical implications with regard to the two notions are intended.

6. Please note that the newsfeed articles are not made part of the text analysis.

7. As the content analysis method has interpretative and thus subjective nature, short text units are included in Table 1 and Table 2 to allow readers see the basis for these interpretations.

8. Text units in Table 1 are retrieved from www.studymalaysia.com, accessed December 2016.

9. Text units in Table 2 are retrieved from www.educationmalaysia.gov.my, accessed January 2017. 


\section{REFERENCES}

Anholt, S. 2007. Competitive identity. The new brand management for nations, cities and regions. New York, NY: Palgrave Macmillan.

2005. What is a nation brand? Superbrands. http://www.superbrands.com/ turkeysb/trcopy/files/Anholt_3939.pdf (accessed October 2016).

Bengtsson, M. 2016. Research article: How to plan and perform a qualitative study using content analysis. Nursing plus Open 2: 8-14.

Bernama. 2016. UNESCO recognises Malaysia as TOP 10 preferred international education hubs. http://www.bernama.com/bernama/v8/ge/newsgeneral.php?id=1235472 (accessed August 2016).

Bourke,A.2000.Amodel of the determinants of international trade inhighereducation. Service Industries Journal 20(1): 110-138. https://doi.org/10.1080/02642060000000007.

Burnard, P. 1991. A method of analyzing interview transcripts in qualitative research. Nurse Education Today 11: 461-466. https://doi.org/10.1016/0260-6917(91)90009-Y.

Dinnie, K. 2015. Nation branding: Concepts, issues, practice. Abingdon: Routledge.

Downe-Wamboldt, B. 1992. Content analysis: Method, applications, and issues. Health Care for Women International 13(3): 313-321. https://doi.org/10.1080/ 07399339209516006.

Fan, Y. 2006. Branding the nation: What is being branded? Journal of Vacation Marketing 12(1): 5-14. https://doi.org/10.1177/1356766706056633.

Gade, J. K. 2014. Higher education branding. Copenhagen Business School. http:// studenttheses.cbs.dk/xmlui/bitstream/handle/10417/4789/jess_kamstrup_gade. pdf? sequence=1 (accessed October 2016).

Gilboa, E. 2008. Searching for a theory of public diplomacy. The Annals of the American Academy of Political and Social Science 616(1): 55-77. https://doi. org/10.1177/0002716207312142.

Goi, M. T., C. L. Goi and D. Wong. 2014. Constructing a brand identity scale for higher education institutions. Journal of Marketing for Higher Education 24(1): 59-74. https://doi.org/10.1080/08841241.2014.906017.

Gray, B. J., S. F. Kim and V. A. Llanes. 2003. Branding universities in Asian markets. Journal of Product and Brand Management 12(2): 108-120. https://doi. org/10.1108/10610420310469797.

Gylling, C. and K. Lindberg-Repo. 2006. Investigating the links between a corporate brand and a customer brand. Journal of Brand Management 13(4-5): 257-267. https:// doi.org/10.1057/palgrave.bm.2540269.

Harris, F. and L. de Chernatony. 2001. Corporate branding and corporate brand performance. European Journal of Marketing 35(3/4): 441-456. https://doi. org/10.1108/03090560110382101.

Hawksworth, J. and D. Chan. 2015. The world in 2050: Will the shift in global economic power continue. PwC's Economics and Policy (E\&P) team in the UK. http://www. pwc.com/gx/en/issues/economy/the-world-in-2050.html (accessed November 2016).

Hawthorne, L. 2008. The growing global demand for students as skilled migrants. Washington, DC: Migration Policy Institute. 
Howard, J. 2013. The search for knowledge: How students use digital to choose schools. https:/www.thinkwithgoogle.com/articles/search-for-knowledge.html (accessed October 2016).

Hsieh, H. F. and S. E. Shannon. 2005. Three approaches to qualitative content analysis. Qualitative Health Research 15(9): 1277-1288. https://doi. org/10.1177/1049732305276687.

Information Architecture Institute. 2007. What is information architecture? http://www. iainstitute.org/sites/default/files/what_is_ia.pdf (accessed April 2017).

Kaneva, N. 2011. Nation branding: Toward an agenda for critical research. International Journal of Communication 5: 117-141.

Mohd Ismail Abd Aziz and Doria Abdullah. 2014. Finding the next "wave" in internationalization of higher education: Focus on Malaysia. Asia Pacific Education Review 15(3): 493-502. https://doi.org/10.1007/s12564-014-9336-7.

Olins, W. 2002. Branding the nation - The historical context. Journal of Brand Management 9(4-5): 241-248.

1999. Trading identities: Why countries and companies are taking on each others' roles. London: Foreign Policy Centre.

Opoku, R., R. Abratt and L. Pitt. 2006. Communicating brand personality: Are the websites doing the talking for the top South African business schools? Journal of Brand Management 14(1): 20-39. https://doi.org/10.1057/palgrave.bm.2550052.

Patton, M. Q. 2002. Qualitative research and evaluation methods. 3rd ed. Thousand Oaks, CA: Sage.

Samokhvalova, A. 2015. Transformation of the higher education system in Malaysia: APEX Initiative and world class university. Bandar Baru Nilai, Malaysia: Universiti Sains Islam Malaysia Press.

Sataøen, H. L. 2015. Higher education as object for corporate and nation branding: Between equality and flagships. Journal of Higher Education Policy and Management 37(6): 702-717. https://doi.org/10.1080/1360080X.2015.1102822.

Szondi, G. 2008. Public diplomacy and nation branding: Conceptual similarities and differences. Netherlands Institute of International Relations "Clingendael". http:// peacepalacelibrary.nl/ebooks/files/Clingendael_20081022_pap_in_dip_nation_ branding.pdf (accessed September 2016).

Zhang, Y. and B. M. Wildermuth. 2009. Qualitative analysis of content. In Applications of social research methods to qualitative studies in information and library, ed. B. Wildermuth, 1-12. http://www.ils.unc.edu/ yanz/Content_analysis.pdf (accessed August 2016). 